\title{
AGRICULTURE ON THE CENTRAL PLATEAU AND COASTAL BAY OF PLENTY
}

\author{
B. G. KOLLER \\ Senior Advisory Officer, MAF, Roțorua
}

THE area to be discussed is on the Central Plateau and part of the coastal Bay of Plenty, and is of approximately $9520 \mathrm{~km}^{2}$.

Some 3000 farmers are carrying approximately 300000 dairy cows, 2000000 sheep, 300000 beef cattle and 10000 deer, and there is a marked move towards diversification, particularly into kiwifruit growing and other subtropical fruits on the coastal strip.

\section{CLIMATE, SOILS, AND VEGETATION}

In brief, the central volcanic plateau is 300 to $800 \mathrm{~m}$ above sea level and this gives a winter climate not unlike many parts of the South Island with up to 80 frosts a year. These are frequent during the May-August period but can occur in any month. Rainfall averages 1200 to $1500 \mathrm{~mm} /$ year. with summer droughts. The coastal strip has a much more moderate climate, with fewer frosts but a similar rainfall distribution. There are 2400 sunshine hours per year.

Yellow-brown pumice soils cover most of the central North Island within a circle centred on Lake Taupo and bounded in the north by the Bay of Plenty, in the south by Waiouru, in the east by Gisborne, and in the west by Taumarunui. The dominant soils are Taupo soils formed from rhyolitic ash showers. Material from these showers tends to be deeper and coarser close to source, and particle size and thickness of deposit diminish with distance (Ref: W. A. Pullar and K. S. Birrell, N.Z. Soil Survey Report, 1973). There appear to have been three major eruptions from Taupo, the most recent being about A.D. 120. In many areas these soils are covered to varying depths with later, more local ash showers. Mud deposits (the latest of these coming from the Mount Tarawera eruption in 1886) are present in small localized areas. The pumice soils in their natural state are low in many elements.

Mixed podocarp broadleaf forest predominated prior to the eruptions, but was replaced through most of the area by manuka and bracken fern. Patches of broadleaf shrubs and forest occupy the more favoured sites, with tussocks and native grasses on the more exposed areas and in frost hollows. 
PROCEEDINGS N.Z. GRASSLAND ASSOCIATION

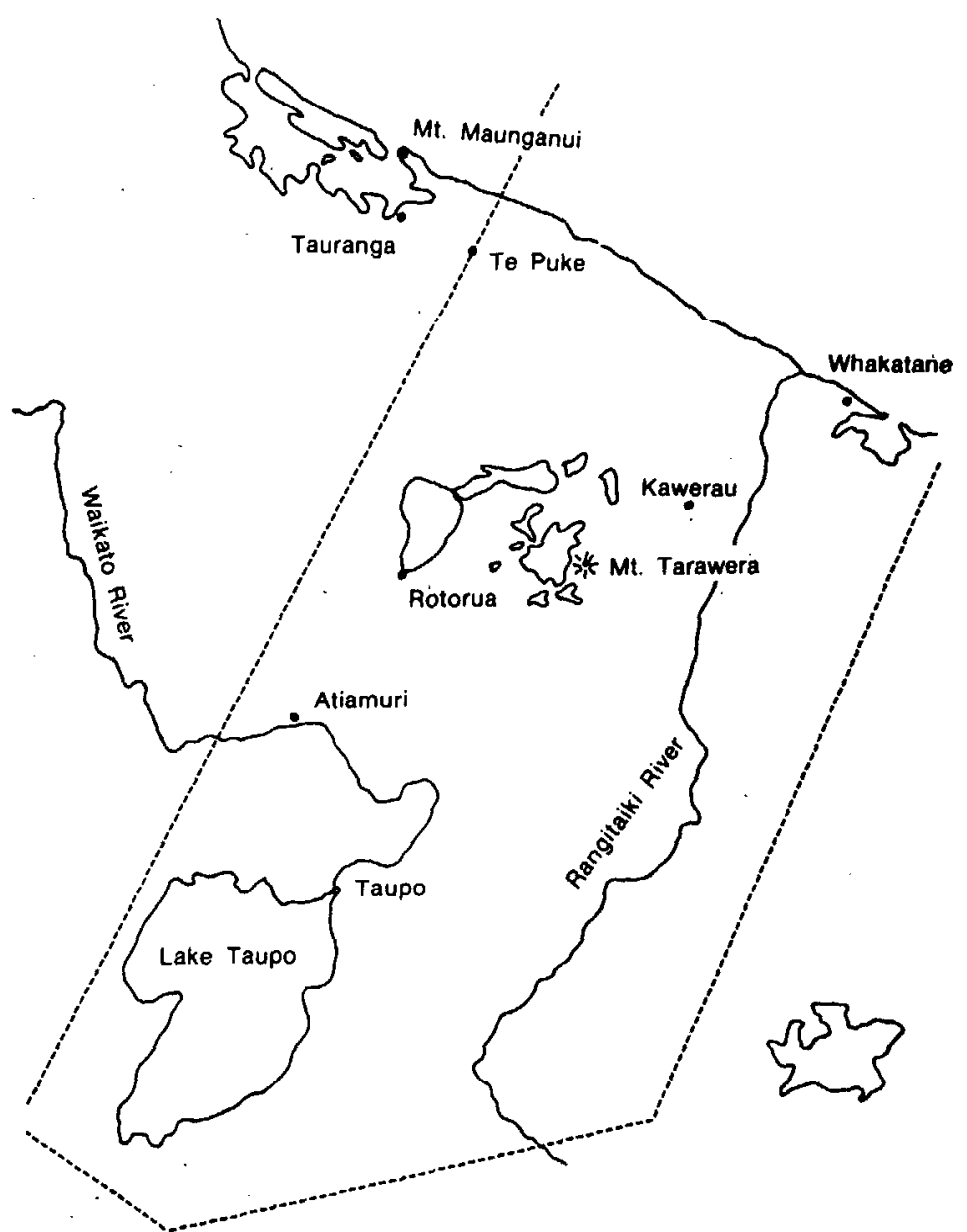

Fic. 1: Central Plateau and coastal Bay of Plenty.

\section{AGRICULTURE}

Farming on the Central Plateau has been developed mainly in the last 30 years. The coastal Ray of Plenty is older, having been farmed for some 100 years. Early land development was to burn and sow seed on. the ash. No artificial fertilizers were used, and the low natural fertility of the soil resulted in the survival of only the low fertility-demanding species such as browntop, danthonia, and ratstail. Clover growth was poor and pasture production low. Superphosphate use increased during the 1920s, but it was the 
use of cobalt in the mid-1930s to remedy the "bush sickness" that marked the beginning of modern agriculture in the region. The Lands and Survey Department has over many years been active in developing the area and has been extremely successful. The pumice soils require heavy initial dressings of $1250 \mathrm{~kg} / \mathrm{ha}$ superphosphate, with maintenance topdressing requirements of 500 to $600 \mathrm{~kg} / \mathrm{ha}$ potassic serpentine superphosphate on dairy farms and 200 to $500 \mathrm{~kg} / \mathrm{ha}$ on sheep farms. Boron and copper are sometimes used, while cobalt is necessary for stock health.

Rather than being a backward area, a carryover from the precobalt, pre-lucerne, pre-kiwifruit days, this is the fastest-developing farming and horticulture region in New Zealand.

Export horticulture is expanding rapidly on the coast, although this is at the expense of part of the dairy industry.

Dairy production has increased by $65 \%$ in the last 10 years on the Central Plateau, with top farmers approaching $400 \mathrm{~kg}$ milkfat/ha. On the more climatically favoured coast, dairy production has reached $600 \mathrm{~kg}$ milkfat/ha on some farms.

Sheep production is increasing, but not at the same rate as dairying. Lambing percentages have risen about $10 \%$ over the last 10 years, but wool production has been static.

The area has accepted the challenges and profits of deer farming and some 140 farmers now have deer, making this perhaps the most intensive area in the country.

Maize is the major field crop grown (mainly in the coastal climatic area), but other process crops such as asparagus are on the increase.

\section{Pasture Production}

Like most areas this varies considerably depending on such factors as weather, soil moisture, management, and species present. Yields range from 5000 to $14000 \mathrm{~kg} / \mathrm{ha} \mathrm{DM}$ from pasture, with some lucerne stands producing at their best over $18000 \mathrm{~kg} / \mathrm{ha}$ DM per annum. Lucerne generally outyields pasture in most seasons.

Special mention must be made of the impact that lucerne has had on farming in the area. Lucerne grows very well because its deep root system gives it drought tolerance. It is also resistant to grass grub. In the Central Plateau area lucerne is now grown on $25 \%$ of all the area in dairy farms and on about $10 \%$ of sheep farms. The range is from no lucerne up to almost $100 \%$ depending on circumstance. Lucerne is also important on the more drought-prone areas of the coastal Bay of Plenty. 
After several seasons with good rainfall during the $1960 \mathrm{~s}$, confidence was high. The 1969-70 drought caused severe feed shortages. Thousands of animals went out of the district to grazing and many hundreds of tonnes of supplementary feed were purchased. At that stage few people were using lucerne, and traditional pastures under drought stress were overstocked and quickly reverted to browntop and other poor species. Severe grass grub infestation followed in many areas and the drier seasons continued. Pastures opened up, and the incidence of noxious plants such as nodding thistle increased markedly. Some erosion also followed the lack of pasture cover on steeper areas, bringing the knowledge that some areas had been developed from bush that would have been better left in trees. Many of these areas are now back in trees.

It is a credit to the. agriculturists, particularly in the Central Plateau area, that they learnt from the problems of that early 1970 period and adopted technology and management systems that were shown to be more suitable for this area. Last year, just 8 years later, a climatically more severe summer drought than that of 1969-70 had minimal effect on the area. Production was down. but very few animals left the district, little feed was purchased, and production the following season was maintained or improved. Lucerne areas on the Central Plateau increased over $300 \%$ from 1970 to 1978 , and although it was not the only factor involved, it was a major one.

\section{DAIRY FARMING}

Most dairy farmers in the area are seasonal suppliers, but some farmers supply town milk companies in Tauranga, Whakatane and Rotorua. Dairying is more concentrated on the flat to gently undulating land, but some quite steep areas are farmed. Farms range from 40 ha, with the average around 60 ha. Production varies considerably from 90 to $200 \mathrm{~kg}$ milkfat per cow and 200 to $610 \mathrm{~kg}$ milkfat/ha. Herd size averages 115 cows.

On the Central Plateau lucerne is grazed by dairy cows to a greater extent than in any other area in New Zealand. The advent of bloat drenching along with an intensive advisory programme in the early 1970 s was largely responsible for its use as a grazing proposition.

\section{SheEp Farming}

Most of the sheep farms are on the rolling to hilly land and average about 200 ha and 2200 stock units (11 to 12 s.u./ha), 
The present aim is to sell most lambs prime. Rotational grazing systems are widely used. Greater subdivision, the use of lucerne where possible, and suitable grazing systems will see greater production from the area. More feed will be grown and better utilized, and better weed control will be achieved than at present.

\section{Beff Cattle}

Beef cow numbers are declining and are unlikely to increase. High wintering costs, lack of flexibility during droughts, low profitability, and greater erosion risks on steep country are reasons for the reduction.

\section{HORTICULTURE}

The success of the kiwifruit industry at Te Puke, and now throughout the coastal Bay of Plenty, focused attention on the potential value of diversification of primary production in New Zealand. As a result of the kiwifruit success, "diversify" has become a catchword. The area planted in horticultural crops now exceeds 3500 ha and much greater areas are being sheltered (shelter breaks planted) for future plantings.

The Bay of Plenty is the most important district for subtropical 'fruits such as kiwifruit, passionfruit, tamarillos, avocados and feijoas. Kiwifruit is the most important crop grown and in 1979 earned some $\$ 30$ million in overseas exchange.

Over $50 \%$ of the citrus plantings are in the Bay of Plenty, producing over $50 \%$ of New Zealand production. Pipfruit, stonefruit, berryfruit, vegetables, nursery plants and flowers (for local and export markets) are also produced.

The success of these crops, particularly kiwifruit, and the large profits eventually realized per hectare, are attracting investors in large numbers to the area. Land values for suitable land are as high as $\$ 30000 /$ ha, with the average nearer $\$ 20000$ / ha for bare land. This is obviously having a significant effect on traditional grassland farming systems in the area, but overall the development is a logical, progressive one.

\section{CONCLUSION}

Overall, the future of the pumice country is bright. The coastal Bay of Plenty is capitalizing on its climate and intensifying production of traditional grassland products and horticulture crops. 
The Central Plateau is not widely recognized as a top grassland area, and so land prices are relatively lower. This attracts keen young men and women to purchase their first farm in the area, and they bring high levels of skills and enthusiasm. More than any factor, these people are the reason for rapid progress in the past decade, and will be so in the future as well.

For a recently developed area the Bay of Plenty-Central Plateau is already producing at a very satisfactory level, but I believe that the next 10 years will see improvements from the area even greater than the past. 